\title{
PHYSICAL AND CHEMICAL COMPOSITION OF WATER IN LAKE KARA-KIR
}

\author{
Odilova Makhfuza \\ Teacher of Biology Department, Bukhara State University, Uzbekistan
}

\begin{abstract}
Lake Kara-kir is located in the northwest of the Bukhara oasis. The total area of the lake is 26.5-27.2 thousand hectares. The physicochemical composition of lake water changes depending on the seasons of the year. the fact that the amount of chlorides contained in water is $3.6-3.7 \mathrm{~g} / \mathrm{l}$, and sulfates in high concentration $5.0-5.2 \mathrm{~g} / \mathrm{l}$, indicates that the degree of salinity occurs due to chloride -sulphates. The readings for dissolved cislarod in water vary, mainly depending on the intensity of photosynthesis and aeration of the water
\end{abstract}

Keywords: chloride, sulfate, photosynthesis, Karakir, seasonality, reservoir, lake, mineral substances, pelagial.

Kara-Kir natural lake (lake system) is located in the northwest of the Bukhara oasis. The black-andwhite collector water was formed due to accumulation. The northern collector is the main source of lake water. No water is taken from the lake, the bulk of the water is reduced due to evaporation and filtration. Water enters the lake through the northern collector at $30-40 \mathrm{~m} 3 / \mathrm{sec}$, but there is no possibility of discharge. As a result of the increase in collector water in winter and spring, the area of the lake reaches 26.5-27.2 thousand hectares due to the formation of small ponds.

During the hot summer days, evaporation and filtration are high, and the area of the lake is significantly reduced to 10-12 thousand hectares due to a decrease in the amount of water entering the lake to 5-10 m3 / sec. The maximum depth of the lake (Large Black Mountain) is 7-8 meters, the average depth is 2.0-2.5 meters, the minimum is 0.7-1.8 meters. The maximum depth of the Black Sea lake is $5-10 \%$ of the total area, the average depth is $15-20 \%$, the minimum depth is $70-80 \%$ $[1,2,3]$.

Research methods. Analysis of the physical and chemical state of water was carried out in the field and in laboratory conditions. Under field conditions, water temperature, color, clarity, turbidity, and $\mathrm{pH}$ were determined. All other parameters of the water were determined under laboratory conditions. Water analysis was analyzed by the methods of Yu.Yu. Lure and NS Stroganov in the Scientific Laboratory of Biotechnology and Ichthyology of Bukhara State University and the Scientific Laboratory of the State Committee for Ecology and Environmental Protection [5,6].

Research results. In studying the physical properties of water, attention was paid to the clarity, color, temperature of the water. The water is clear, the clarity is seasonal. The highest rate is $2.8-3.0$ meters in January-February. In summer, the figure is 0.5-1.5 meters. (On the Sekki disc). Water temperature is closely related to air temperature. During the year, the average air temperature was 22 $0 \mathrm{C}$ and the water temperature was $15.20 \mathrm{C}$ (Fig. 1). 




Figure 1. Average water and air temperature in Kara-Kyr Lake

In recent years, the water of Lake Kara-Kyr has been frozen during the winter months. On December 17,2015 , the shores began to freeze. However, freezing was not observed due to the wave size at the depth of the pelagic zone 5-7 m. Seasonal samples were collected to determine the chemical composition of the Black Sea water.

The water content was analyzed on several indicators. The results of the study of the hydrochemical composition of the Kara-Kyr and Northern ditches show that the amount of minerals and dissolved oxygen in the water depends on the seasons. The suspended solids in the water of the Black Mountain Lake were found to be more abundant than in the North Ditch, which is the lake's water supplier. Due to the lack of water flow in the lake, the performance of suspended solids is high due to the active development of phytoplankton and zoplankton in spring, summer and autumn. Due to the large amount of dry waste in the lake in summer and autumn, and the high temperature in summer and autumn in Bukhara region, an increase in dry waste as a result of water evaporation. It was found that the content of chlorides in black water is $1.8-3.7 \mathrm{~g} / 1$, sulfates in high concentrations - $5.0-5.2$ $\mathrm{g} / \mathrm{l}$, seasonal due to water evaporation, salinity due to chlorides sulfates.

Biogenic elements in water are assimilated by nitrogen and phosphorus compounds, low and high plants in the lake. Therefore, the amount of oxygen in the water increases and they are maintained at the rate of 6.6 - $6.8 \mathrm{mg} / 1$ during the season (Table 1).

Hydrochemical indicators of water of Kara-Kyr lake of Bukhara region for 2018-2019

\begin{tabular}{|c|c|c|c|c|c|}
\hline № & Identified indicators & Spring & Summer & Autumn & Winter \\
\hline 1 & Suspended substances, $\mathrm{mg} / \mathrm{l}$ & $84,9 \pm 2,2$ & $90,2 \pm 3,3$ & $89,3 \pm 3,5$ & $78,0 \pm 2,8$ \\
\hline 2 & $\mathrm{pH}$ & $6,0 \pm 0,09$ & $7,2 \pm 0,1$ & $6,0 \pm 0,09$ & $6,0 \pm 0,09$ \\
\hline 3 & Dry residue, g / & $10,6 \pm 0,3$ & $11,5 \pm 0,4$ & $11,0 \pm 0,3$ & $9,8 \pm 0,3$ \\
\hline 4 & Oxygen dissolved in water, mg /l & $6,7 \pm 0,21$ & $6,7 \pm 0,23$ & $6,8 \pm 0,15$ & $6,8 \pm 0,24$ \\
\hline 5 & $\begin{array}{c}\text { Biochemical consumption of oxygen, } \\
\mathrm{\Gamma O} \mathrm{O}_{2} / \mathrm{I}\end{array}$ & $20,3 \pm 0,6$ & $17,1 \pm 0,6$ & $13,9 \pm 0,5$ & $11,7 \pm 0,4$ \\
\hline 6 & Nitrogen is ammonia, $\mathrm{mg} / 1$ & $2,0 \pm 0,06$ & $1,8 \pm 0,06$ & $2,0 \pm 0,07$ & $2,0 \pm 0,08$ \\
\hline
\end{tabular}




\begin{tabular}{|c|c|c|c|c|c|}
\hline 7 & Nitrites, $\mathrm{mg} / \mathrm{l}$ & $0,05 \pm 0,001$ & $0,03 \pm 0,001$ & $0,03 \pm 0,001$ & $0,04 \pm 0,001$ \\
\hline 8 & Nitrates, $\mathrm{mg} / \mathrm{l}$ & $3,2 \pm 0,1$ & $5,2 \pm 0,2$ & $5,8 \pm 0,26$ & $5,5 \pm 0,2$ \\
\hline 9 & Chlorides, g / & $1,8 \pm 0,06$ & $3,6 \pm 0,12$ & $3,7 \pm 0,17$ & $1,8 \pm 0,07$ \\
\hline 10 & Sulfates, $\mathrm{g} / \mathrm{l}$ & $5,0 \pm 0,24$ & $4,6 \pm 0,18$ & $5,2 \pm 0,21$ & $5,1 \pm 0,2$ \\
\hline 11 & Phosphates, $\mathrm{mg} / \mathrm{l}$ & $0,1 \pm 0,003$ & $0,1 \pm 0,004$ & $0,1 \pm 0,003$ & $0,1 \pm 0,003$ \\
\hline 12 & Iron, $\mathrm{mg} / \mathrm{l}$ & $0,1 \pm 0,002$ & $0,1 \pm 0,003$ & $0,1 \pm 0,004$ & $0,1 \pm 0,003$ \\
\hline
\end{tabular}

The daily rate of dissolved oxygen in water depends mainly on the intensity of photosynthesis and water aeration. The average rate of dissolved oxygen in water in 2018 is $6.26 \mathrm{mg} / 1$ saturation rate of $75.1 \%$. Only in the strong wave does the dissolved oxygen content in water increase from 9.5 to 10.2 $\mathrm{mg} / 1$ (Table 2).

Daily indicator of dissolved oxygen in water in Karakir Lake.

\begin{tabular}{|c|c|c|c|c|c|c|c|c|c|c|}
\hline \multirow{2}{*}{ Time } & \multicolumn{2}{|c|}{ May } & \multicolumn{2}{|c|}{ June } & \multicolumn{2}{|c|}{ August } & \multicolumn{2}{|c|}{ September } & \multicolumn{2}{|c|}{ December } \\
\cline { 2 - 11 }$/ 1$ & $\begin{array}{c}\text { Saturation } \\
\text { курр- } \\
\text { чи\% }\end{array}$ & $\begin{array}{c}\mathrm{Mg} \\
/ 1\end{array}$ & $\begin{array}{c}\text { Saturation } \\
\%\end{array}$ & $\begin{array}{c}\mathrm{Mg} \\
/ 1\end{array}$ & $\begin{array}{c}\text { Saturation } \\
\%\end{array}$ & $\begin{array}{c}\mathrm{Mg} \\
/ 1\end{array}$ & $\begin{array}{c}\text { Saturation } \\
\%\end{array}$ & $\begin{array}{c}\mathrm{Mg} \\
/ 1\end{array}$ & $\begin{array}{c}\text { Saturation } \\
\%\end{array}$ \\
\hline 9 & 5,7 & 52,8 & 4,8 & 68,6 & 6,8 & 54,3 & 4,5 & 64,0 & 6,0 & 85,7 \\
\hline 12 & 6,2 & 60,0 & 5,9 & 84,3 & 7,0 & 57,1 & 5,5 & 78,6 & 6,0 & 85,7 \\
\hline 15 & 6,6 & 94,3 & 6,5 & 92,8 & 8,5 & 121,4 & 6,0 & 85,7 & 6,5 & 92,8 \\
\hline 18 & 5,9 & 84,3 & 8,9 & 127,1 & 8,0 & 114,2 & 5,8 & 68,6 & 5,0 & 71,4 \\
\hline 21 & 5,5 & 64,0 & 6,0 & 85,7 & 5,3 & 75,7 & 5,9 & 55,7 & 5,0 & 71,4 \\
\hline $\begin{array}{c}\text { Mediu } \\
\text { m cha }\end{array}$ & 6,4 & 48,6 & 6,42 & 91,7 & 5,9 & 84,3 & 6,5 & 70,0 & 6,7 & 81,4 \\
\hline
\end{tabular}

The level of oxygen consumption in the water of the Black Sea is much higher. The reason for this is the eutrophication of the lake. At a depth of 4 to 5 meters, the dissolved oxygen content in the water is much lower at 2.5 to $3.0 \mathrm{mg} / 1$. This is due to the abundance of organic residues at the bottom of the water and the lack or non-occurrence of circulation. Oxygen saturation of water is achieved through invasion. High water temperatures and high levels of organic matter lead to a decrease in the amount of dissolved oxygen in the water [4]. The amount of dissolved organic matter in water is 9.8 - $20.3 \mathrm{mgO} 2 / 1$, and their oxidation also requires considerable oxygen.

The study of the physicochemical composition of the water of Kara-Kyr Lake proved that the salinity is high and seasonal. In addition, the increase in the amount of water entering the lake from the Northern Collector in the spring and the decrease in the summer also led to higher mineral values.

\section{References}

1. Buriev, S.B. and Kobilov, A.M. (2019) The Region's Aquatic Vegetation of Lake Kara-Kira Bukhara. ACADEMICIA: An International Multidisciplinary Research Journal, 9, 5-11. https://doi.org/10.5958/2249-7137.2019.00072.7

2. Odilova M.O. "IMPROVING THE PEDAGOGICAL POTENTIAL OF BIOLOGY TEACHERS USING COMPUTER PROGRAMS." International Engineering Journal for Research \& Development 5.9 (2020): 4-4.

3. Mukhtorovich, K.A. and Burievich, B.S. (2019) Distribution of High Water Plants of Lake Karakir in Bukhara Region in Ecological Groups. American Journal of Plant Sciences, 10, 22032207. https://doi.org/10.4236/ajps.2019.1012155 
4. Buriev, Sulaymon Burievich and Kobilov, Aziz Mukhtorovich (2019) "Prevalence and systematics of high water plant species of Karakir lake in Bukhara region," Scientific Bulletin of Namangan State University: Vol. 1: Iss. 10, Article 18. https://uzjournals.edu.uz/namdu/vol1/iss10/18

5. Пименова Е.В. Химические методы анализа в мониторинге водных объектов.-М.: Изд-во ФГБОУ ВПО Пермская ГСХА, 2011.- 138 с

6. Лурье Ю.Ю. Унифицированные методы анализа вод. - М.: Химия, 1973. - 376 с

7. Строганов Н. С. Практическое руководство по гидрохимии. - М.: Изд-во Моск. ун-та, 1980. - 257 c. 